\title{
Child Abuse, Exploitation and the Quest for a Better Life in Sefi Atta's Everything Good Will Come (2004) and Swallow (2010) and Toni Morrison's The Bluest Eye (1970)
}

\author{
Babacar Diakhaté \\ Laboratoire d’Études africaines et postcoloniales, Université Cheikh Anta Diop, Dakar, Sénégal \\ Email: diakhatebabacar83@hotmail.fr
}

\begin{abstract}
:
This Article brings to light the topicality of the 21st century African and African-American female novel especially in Sefi Atta's Everything Good Will Come and Swallow, and Toni Morrison's The Bluest Eye. As the African traditional societies have much progressed, this work aims at showing that the African and African-American female novel has also progressed thematically speaking. It addreses new literary trends like Adoption, Rape, Incest, Child Abuse, Emigration and Identity Issues.
\end{abstract}

Keywords:

rape; incest; suicide; adoption; immigration

\section{Introduction}

The African and African-American women traditional lives have positively and significantly changed in all fields. This change has an impact on their social, political and economic lives, which in turn has some repercussions in their topicality. Instead of postraying problems experienced by a community or a group of individuals, they rather show what their characters have individually experienced. In Everything Good Will Come, Swallow and the Bluest Eye Sefi Atta and Toni Morrison address cases of rape, incest and the quest for identity. Indeed, the authors use Sheri, Rose and Pecola to depict the exploitation and manipulation of women by man. These writers tacle social issues that have been taken as taboo. It is very difficult or even impossible to open a newspaper or listen to the radio or even watch TV programmes without bumping into such themes. This article consists in displaying how women are individually victimized by man. It also depicts the problematic of the "feminization of Emigration" and the loss of identity.

\section{Review of Literature}

\subsection{Child Abuse and Exploitation}

The African-American and African citizens have been victims of many evils that have left sequels in the characters' minds: slavery, discrimination, colonialism, neocolonialism, child abuse, exploitation, etc. In Swallow and Everything Good Will Come and The Bluest Eye respectively by Sefi Atta and Toni Morrison, the authors are very concerned about African and AfricanAmerican women living condition.

\section{a. Rape, Incest and Adoption}

Rape, Incest and Adoption have been the underlying issues in the writings of Toni Morrison and Sefi Atta. These African and African-American women writers show several ways in which the above-mentioned evils have affected the human condition and their effects are still felt in the victims' daily activities. 
Child abuse is epitomized here by characters such as Pecola in Toni Morrison's The Bluest Eye and Sheri in Everything Good Will Come. Pecola and Sheri are protagonists who have been raped and oppressed in different ways by men. Morrison and Atta explore the issues of male oppression over females like rape and incest. Indeed, Pecola's father rapes her to win for himself a memory of the strong self he lost in a world that oppresses him. In Everything Good Will Come, Daramola participates in raping Sheri. As the writer reveals:

Sheri was lying on the seat. Her knees were spread apart. The boy in thee cap was pinning her arms down. The portly boy was on top of her. His hands were camped over her mouth; Daramola was leaning against the door (Atta, 2004:68).

Similarly, in Buchi Emecheta's the Family, the first person to rape Gwendolen is a close family friend, "uncle" Johnny. He is a man whom Gwendolen is taught to trust and obey. She is raped at home by her own father while her mother is away from home.

Like Pecola and Sheri and Gwendolen, Xuela in The Autobiography of my Mother also experiences the same violation.The loss of her mother and her missing father who has given her to one of his so-called friend to protect and adopt her on his behalf are responsible for her situation. His so-called friend Jacques Labatte repeatedly rapes her. LikeToni Morrison in The Bluest Eye, Sefi Atta shows how the black character has been a victim of rape and incest in Everything Good Will Come through Sheri. As a matter of fact, at the beginning of the book, young Enitan witnesses the rape of her friend, Sheri. She puts:

Bad girls got raped. We all knew. Loose girls, forward girls, raw, advanced girls. Laughing with boys... thinking she was one of them... It was her fault (Atta, 2010, 65).

Even though she does not address her feelings about the event that she has just witnessed, Enitan shows her fear of becoming a victim like her friend. An overview of the life and predicaments of Pecola's parents offers an explanation of the abuse of Pecola. Cholly defines himself as a "free man", an outsider in the society of the black community. He does not know the tenderness of any father hence his attitude towards his own daughter. The fact that he abuses his own daughter is brought about by the lack of upbringing that he could have benefited from his absent father. As Toni Morrison writes:

He was abandoned in a junk heap by his mother and rejected for a crape game by his father, there was nothing more to lose. He was alone with his own perceptions and appetites, and they alone interested him (Morrison, 1970: 43).

Pecola's mental destruction is caused by her ignorance of the values that have not been transmitted to her by her mother, which makes her vulnerable to the effects of Colonialism.

\section{b. Child's Physical and Economic Exploitations}

Child abuse, exploitation and victimization have also been engendered by the rapid transformation of many African societies causing the spreading out of many 'parentless' children or even beggars in the streets. Those who top the bill of responsibilities are first of all those Arabic teachers or so-called "Quran teachers"who take beggars as sources of financial advancement. They expose them to the streets all day long to ask for money. On the one hand, their irresponsible parents must also be blamed for sending away their kids at early age. On the other hand, the lack of a serious policy of governmental authorities to put an end to that issue should be taken into account as well. 
Exploitation appears clearly in Sefi Atta's News from Home and Swallow through the character of Fatima's mother and some unionists who organize themselves to defend doctors' rights. Fatima's mother is put in jail by her own husband who accuses her of adultery and in Zamfara the women who are accused of adultery are punished. In reality she has never committed adultery. She is impregnated by her own husband. Miriam Makili in News from Home stands as a defender of married women's rights: I am against underage marriage. The psychological effects alone are bad enough; some women develop cancer of the cervix (Atta, 2010: 33).

In Swallow, doctors go on strike because the government delays their salaries, which they regard as economic exploitation. They say: let them pay us regularly, first. Don't delay our salaries and improve our working condition. (Atta, 2010: 33) Tolani asserts:

I couldn't imagine going to the hospital. If I were dying, I would rather die at home.

Patients had to buy their own predicaments, IV drips and bandages. There were never enough beds and during operations they had power cuts. Patients died from simple oxygen. They had to pay deposits before they were admitted and they are given oily meals and slept on dirty bed sheets. To stop it, the nurses were rude. The hospital was, of course, not private but government-funded, One of our very best (Atta, 2010: 62).

Structural exploitation results, most of the time, from the problem of school dropouts. As a solution, the youths who are unable to continue their education must be given the opportunity to learn other skills in order to make themselves useful in their societies. Some examples show that the plight of the African child suffering from different shortcomings on the part of both leaders and parents has also become a central theme in the female African

\section{Discussion}

\section{Emigration and the loss of Identity}

Emigration and its bad effects have become so wide-spread that many African and African-American women writers have strongly introduced this theme into their fictions. The courage of the hopeless young Africans to defy the Mediterranean Sea is just enough to show to what extent they are committed to going to Europe or America.

Their departure for the West is also sparked by many other causes: they flee civil wars, dictatorship, terrorism and the poverty that prevail in their countries. They are victims of political instabilities and disillusionment resulting from corruption, embezzlement of funds, money laundering and revolts, which pushes Third World characters to move out of the African continent hoping for the fulfillment of their dreams. The characters are seen as the new breed of African diaspora comprising of people in short term exile abroad. For most characters, their incomes do not enable them to have a decent life. They can't support their families to pay for a good education for their children. Characters like Violet indulges in prostitution but through the help of her fiancé Fidele she comes back to Nigeria to run a salon that she calls Sympatico.

In Toni Morrison's and Sefi Atta's writings, respectively, The Bluest Eye and Swallow, characters suffer from alienation and homesickness all brought about by a political system and uneasiness among foster families. Sefi Atta describes the hardships that the characters undergo with a corrupt political system by these words:

Salako steals everything from the bank, taking money from customers, taking bribes. Salako opens an account for Big Man... the loan is never repaid and that is just the beginning. All those dormant account, Salako is using them as his personal 
accounts. He is a thief like any other else in this god forsaken country (Atta, 2010:15).

Swallow, as its noun suggests, does not only reveal the unpunished and corrupt political system in Nigeria, but it also depicts the way in which Nigerian female immigrants turn themselves into whore and drug dealers. In fact, OC, one of the most notorious drug dealers who shuttles back and forth between America and Nigeria, wants women like Rose and Tolani to take drugs to overseas, in America. They swallow or put them in their private parts. Rose confesses: My sister, I am not ashamed. Being poor is what I am ashamed of. Being poor is what you should be ashamed of (Atta, 2010: 139)

Rose' indulgement in prostitution is engendered by poverty. As a modern woman who wants to be financially independent. She resorts to all necessary means to reach her goal. Rose compares her undignified attitude to what her political leaders do and whom she accuses of being responsible for her loss of values as she puts:

Our heads of state steal our directors' steal. Who ask where their money comes from? People praise them. They run after them and beg them to spread their wealth. I am tired of being poor (Atta, 2010: 139).

In Swallow Eve does not behave well in America. According to female African immigrants all means are good to have money. Indeed, they do not want to come back in their respective families empty-handed. Eve puts:

That was my intention to ruin the Daregos' lives only to find a legitimate way of staying and earn enough money to continue sending money home... We Africans, we only get attention when we need help, when we have no hope, and Oh Yes, most especially when we are naked (Atta, 2010: 197).

Morrison's southern folks in The Bluest Eye migrate to Lorain, Ohio because they need jobs in the same way as Ogun, Violet, and Sisi, leave their African countries for London and America. Their respective situations in their countries of origins, marked by poverty, inequality, sexist, stereotypes, capitalism and patriarchy among other exterior forces, have contributed to their displacements from the village to the city and further from Africa to western countries.

\section{Conclusion}

Child abuse and exploitation are also a literary trend found in the novels of Sefi Atta and Toni Morrison respectively in Everything Good Will Come and Swallow and The Bluest Eye through their characters Sheri and Pecola. The research has discovered that the victims of abuse are menaced by their abusers and they run the risk of reprisals. Therefore, it is impossible for the victims to denounce or do a report of rape to expect a trial. The victims are in difficulty to find pieces of evidence to be submitted to the prosecutor to eventually expect their abusers to be arrested. The victims and their families may need a diversity of health services, like mental health support and treatment, family support about the rape and advocacy to demand arrest and compensation. 


\section{References}

Adichie, Chimamanda Ngogi (2004).Purple Hibicus. Anchor.

Alkali, Zaynab (1988). The Stillborn. London: Heinemann.

Angelou, Maya (2009). I know Why the Caged Bird Sings. Ballantine Books.

Atta, Sefi (2004). Everything Good Will Come. Interlink book.

... (2010). Swallow, interlink book.

..., (2010). News from Home. Interlink book.

Dieng, Gorgui (2003) "Universality and Topicality in African Novel"published in International Journal of Humanistic Studies, volume 2.

...,( 2011) "Prospective perspectives on the 21th Century Female African Novel"appeared in "Cours Nouveau'.

..., (1989). The Family, London: Heinemann.

... (2002). the New Tribe. African writers series, London: Heinemann.

... (1970). the Bluest Eye. USA: Washington Square Press Books.

Nwapa, Flora (1966). Efuru, London: Heinemann African Writers Series.

SY, Kadidia (2008) “Women's Relationships: Female Friendship in Toni Morrison's Sula and Love, Mariama Ba's So Long A Letter and Sefi Atta's Everytbing Good Will Come”, Dissertation, Georgia University. 